\title{
Informandiga voodis. Lähedus ja intiimsed teemad välitöödel
}

\author{
Andreas Kalkun
}

Teesid: Artiklis arutatakse refleksiivselt välitöödel toimuva üle, keskendudes seksuaalsuse ja lähedusega seotud küsimustele ning probleemidele, mis võivad tekkida intiim- ja tabuteemade käsitlemisel. Tänapäevastel välitöödel eeldatakse selle läbiviija suurt empaatiat ning võimet saavutada oma vestluspartneriga usalduslik ja lähedane side. Samas kuuluvad välitööde juurde sageli uurija või informandi füüsilist heaolu ja mugavust puudutavad kompromissid. Kuigi uurija seksuaalsust ja religioosset tausta on olnud tavaks "objektiivsete" uuringute nimel varjata, on ka need väljal koos uurija elukogemuse ja eelistustega. Kuigi tänapäeval on tavaks rõhutada õnnestunud välitööde dialoogilisust, on nende struktuuri enamasti peidetud hierarhilisus. Välitööd on üldjuhul eesmärgistatud ja korraldatud nii, et informandid ei pruugi päris täpselt tajuda, mis põhjustel teatud teemasid vestluses käsitletakse või üleüldse lähedast suhtlemissituatsiooni luuakse. Seksi, läheduse ja tabudega seotud teemadel näibki olevat võime paljastada välitööl toimuva suhtluse mingeid varjatud aspekte, näiteks soo, seksuaalsuse ja võimuga seotud struktuure ja hierarhiaid.

Märksõnad: intiimsus, seksuaalsus, tabuteemad, välitööd 
Ann elas vaeselt. Pisikese majahüti ees valvas purulahja peni, laudamoodi ubrikus oli paar lambakonti ja luine sigudik. Elutuba oli tilluke, sinna mahtus parajasti lauake, väike voodi ja paar pinki. Muud võimalust polnud, meil tuli kahekesi jagada seda ainukest voodit. Olin Annest umbes $40 \mathrm{~cm}$ pikem, suured kondid ei tahtnud kuidagi mahtuda sellesse pisikesse "karpi”. Tänu seinapoolsele äärele, oli jalgade sirutamiseks ainuke võimalus õndlad toetada voodi otsalauale. Uneaeg oli lühike, eideke armastas voodis rääkida. Saime magama kesköö paiku, hommikul kella nelja ajal oli Annel uni läinud, hü̈̈dis: “Ärr üless, kikas kirge ju!" Mis siis ikka, kui vaja siis üles!

Parim jutuhoog oli eidel voodis, sealt sai kuulda rohkesti haruldasi sõnu ja huvitavaid väljendeid. Pliiatsi ja klade võtsin voodisse kaasa, panin padja alla. Vajaduse korral tegin märkmeid pimedast peast kobamisi. (Keem 1962, 37, 38)

Keeleteadlane ja suur murdekoguja Hella Keem kirjeldas niimoodi oma "ainult kaks nädalat" kestnud intensiivset keele- ja rahvaluuleainese kogumist Põlva kihelkonnas Adiste külas elava Ann Rammo (1864-1939) juures 1937. aastal. "Töötamistingimused olid rasked, vähene uni ja kehv toit mõjusid kurnavalt," tõdeb Hella Keem, seletades oma välitööde "lühidust" just kehaliste põhjustega. Murdekoguja ei andnud siiski alla: ta sõitis pärast kaht nädalat kestnud kogumistööd koju, kus püüdis välja magada, ning tuli peagi toidumoonaga varustatuna jätkama oma pooleli jäänud jäädvustamist. Kui 1938. aastal kutsuti Ann Rammo Akadeemilise Emakeele Seltsi poolt korraldatud murdekeele heliplaadistamisele, sõitis Ann rongiga Tartusse, kuid olevat jäänud vagunitrepile seisma "nagu post" ja trepist alla ei astunud. "Mis siis ikka, eit oli pisike, tõstsin ta sülega trepilt maha," kirjeldas Hella Keem raudteejaamas juhtunud seika (1987, 143).

Välitööd on sageli nii vaimselt kui füüsiliselt väga intensiivsed. Äsja veel võõrad inimesed veedavad tunde koos ning vestlevad ka väga isiklikel teemadel. Lisaks intellektuaalsele või vaimsele väljakutsele on see sageli ka väga kehaline kogemus. Jäädvustajad püüavad sageli jäädvustamise õnnestumise nimel sulanduda justkui probleemideta oma vestluspartneri pakutud füüsilisse ruumi ning kohanduda reeglitega, mis selles kodus või külas valitsevad. Hella Keema kirjeldatud välitööolukord, kus jäädvustaja ja jäädvustatav teevad oma tööd kitsas voodis, on nagu sümbolpilt, mis annab edasi välitöödel ette tulevat ebatavalist füüsilist lähedust ning ka oma kehalist autonoomsust ja heaolu puudutavaid kompromisse, mida 
koguja on nõus kogumise õnnestumise nimel tegema. Me ei saa teada, mida arvas Ann Rammo sellest, et pidi magama kaks nädalat kitsas voodis "suure kondiga" võõra noore naisega, kes oli temast "umbes $40 \mathrm{~cm}$ pikem". Samuti ei saa me teada, miks Ann Tartus rongist välja ei tahtnud tulla ning mida ta arvas sellest, kui Hella Keem ta tookord sülle haaras. Ann oma mälestusi ei kirjutanud, ning nagu enamasti ikka, saame välitöödel toimunu kohta teavet vaid jäädvustavalt osapoolelt.

Hella Keem kirjeldab oma välitöömälestustes, kuidas ta püüdis enne igat uue keelejuhiga kohtumist endale sisendada, et see on talle väga lähedane inimene. Ta otsustas, et "viisaka külalisena käitumine" pole otstarbekas ning kujutles iga uue võõra ukse taga ette, et see on ta koduuks ning sisenes nagu "oma inimene" ja hakkas kohe familiaarselt vestlema (Keem 1962, 30). Hella Keem nägi Ann Rammole pööratud keeleteadlaste tähelepanu sugulaste ning külarahva poolt pilgatud vanale ja vaesele vallaslapse emale jõustava ja toetavana. Tema jaoks oli Ann Rammo "suurepäraste vaimuannetega inimene", kelle regivärsside hulk oli selline, et neid oleks võinud laulda mitu päeva järjest (Keem 1987, 143). Ja nii nagu välitöödel ikka võib ette tulla, peavad koostöö nimel kompromisse tegema mõlemad osapooled. Hella Keema ja Ann Rammo puhul oli selliste kompromisside sümboliks kaks nädalat ühises kitsas voodis magamist.

Ka minu kõige esimestel Setomaa välitöödel tuli ette olukord, kus magasin informandi voodis ja tema linade vahel. Olin koos minust kümmekond aastat vanema õpingukaaslannaga Setomaal Saetsuva küllas üksiku vana naise juures, ning ühtäkki oli pime ja liiga hilja, et kuhugi minna. Meie vestluspartner tegi ettepaneku, et jääksime ööseks, millega nõustusime pärast väikest arutelu. Perenaine otsustas, et paneb meid magama abieluvoodisse, kus ta ise tavaliselt magab, ning magab ise samas toas oleval kušetil. Muidugi tegi lahke perenaine vihjeid, kuidas ma nüüd võtan oma "mõrsja" enda juurde magama ja kõigil on hea meel. Mu kaaslane punastas selle peale, aga ilmselt tundus ka talle kohatu sellele pruudi ja peigmehe jutule vastu vaielda. Samamoodi ei kommenteerinud me nagu kokkulepitult loomulikult ka seda, kui perenaine otsustas linu mitte vahetada ${ }^{1}$, vaid heitsime kuulekalt voodisse. Perenaine rääkis

${ }^{1}$ Välitöödel käijate kogemustel talurahva voodilinade, nende puhtuse, mustuse või sootuks puudumisega olen peatunud põgusalt oma doktoritöös (Kalkun 2015, 152). 
veel natuke naljajuttu, kui tuli oli ära kustutatud, kuid jäi ilmselt kiiremini magama kui meie. Hommikusöögilauas piidles perenaine uudishimulikult mu jalgu, kuid mitte kirbuhammustuste pärast, nagu selgus, sest lõpuks küsis ta, mis mu jalanumber on. Saanud selle teada, tõi ta tagatoast kapist kingakarbi, kus olid kergelt läikivast nahast meestekingad. Need olid Tšehhoslovakkias toodetud vanamoodsa tegumoega, kuid peaaegu uued kingad, mis olid kuulunud perenaise kadunud vennale. Kingad olid mulle küll natuke väiksed, kuid perenaine otsustas, et need sobivad mulle hästi. Mul ei jäänud muud üle, kui need vastu võtta.

Niisiis, kuigi need olid meie esimesed välitööd, käitusime nagu külalised ning need füüsilise ruumi ja teatud jututeemadega seotud kompromissid tundusid täiesti iseenesestmõistetavad. Hea koostöö nimel tundusid perenaise kergelt seksuaalse alatooniga naljad ja meie paaripanek asjad, millega tuli lihtsalt leppida. Pealegi tegi ju ka perenaine koostööd: oli nõus meiega rääkima, lasi ennast salvestada ja andis meile öömaja. Lisaks intiimne lähedasele inimesele kuulunud kalliste kingade kinkimise žest, mille tähendus jäi juba tookord lootusetult hämaraks.

Mõtisklen järgnevalt seksuaalsusest, lähedusest ja tabuteemadest seoses folkloristlike või muude humanitaaraladega seotud välitöödega. Reflekteerin eelkõige oma isiklikke kogemusi, kuid seksuaalsuhete ja välitöö teema käsitlemisel tõukun ka antropoloogia klassikute selleteemalistest kirjutistest. Mind huvitavad seksuaalsuse, läheduse ja tabudega seotud teemad selle artikli kontekstis eelkõige seetõttu, et neil paistab olevat võime paljastada välitööl toimuva suhtluse mingeid varjatud aspekte nagu näiteks hierarhiad, võimusuhted ja eelarvamused. On intrigeeriv, kuidas vestluspartnerite afišeeritud lähedus võib osutuda ühtäkki illusiooniks, kui arutada tõeliselt intiimseid ja puudutavaid teemasid või kuidas olmelised, hariduslikud või kogemuslikud erinevused võivad osutuda põhjatuks kuristikuks ka uurija ja tema n-ö lemmikinformandi vahel. Reflekteeringi järgnevalt neid epifaanilisi hetki välitöödel, kus selgub, et uurija ja uuritava arusaamad lähedusest, sobivatest jututeemadest, perekonnasuhetest, seksist, seksuaalsusest või kosjakommetest on lepitamatult erinevad. Kui selgub, et vaatamata kogu empaatiale ja austusele ei tunne uurija end mugavalt informandi linade vahel, tema riideid kandes, tema pakutud jooki juues, sööki süües või käitudes nii, nagu informant näib ootavat. 


\section{Informandi linade vahel. Seks välitööl?}

Välitööde õnnestumiseks on osapoolte omavahelised soojad suhted väga olulised. Samas on välitööde õpikutarkus, et liigne lähedus võib osutuda segavaks, ning igasugust osapoolte intiimset lähedust on peetud täiesti ebaeetiliseks. Samas on siiski selge, et vallalised noored mehed või naised pole võõras kultuuris veedetud pikkadel välitööperioodidel alati saanud või tahtnud neist reeglitest kinni pidada. Eks seetõttu olemegi ilmselt kõik kuulnud sosistatavat lugusid, kus välitöödel keegi on kedagi leidnud või lihtsalt "midagi sellist" on juhtunud.

1967. aastal avaldati tõlge antropoloog Bronisław Malinowski intiimsest poolakeelsest reisipäevikust, kust selgus, et Trobriandi saartel "primitiivse" ühiskonna seksuaalelu uurides oli noor antropoloog pidanud rasket isiklikku võitlust oma "ihade" ja "ebapuhaste" fantaasiatega, mida ta oli tundnud nii kohalike kui ka misjonitööl olevate naiste vastu (Malinowski 1967). Kuigi päevik avaldati postuumselt ning Malinowski lesk oli seda enne avaldamist lühendanud ja tsenseerinud, põhjustas antropoloogi avameelsus (informantide "käperdamised" ja ambivalentne iha "primitiivsete" naiste vastu) suurt diskussiooni ning kohati lausa Malinowski pärandi ümberhindamist (vt Newton 2000, 246). Ka hiljem on antropoloogid oma seksuaalse tabu murdmist väga harva üles tunnistanud. Tuntumaid avameelitsejaid on Paul Rabinow, kes kirjeldas oma üheöösuhet Maroko naisega, keda meesinformant oli talle pakkunud (2007 [1977]). Rabinowi järgi olevat aidanud see seksuaalne afäär tõestada tema mehelikkust ning parandanud tema positsiooni meesinformantide hulgas. Esimene naisantropoloog, kes tunnistas, et on olnud seksuaalvahekorras oma meesinformandiga, oli Karla O. Poewe, kes kirjutas sellest skandaali tekitanud artikli Manda Cesara nime all (Cesara 1982). Hiljem on artiklis "Minu parima informandi kleit" mõtestanud välitöödel tekkiva läheduse ja seksuaalsuhete teemat homoseksuaalse naise vaatenurgast antropoloog Esther Newton, kes tundlikult reflekteerib "liiga lähedast" suhet tema enda ja vanema lesbilise naisinformandi vahel (Newton 1993).

1995. aastal ilmus Don Kulicku ja Margaret Willsoni toimetatud artiklikogumik "Taboo: Sex, Identity and Erotic Subjectivity in Anthropological Fieldwork", mis esmakordselt käsitles avameelselt välitöödel toimuvat nii, et fookuses oli välitööprotsessis osalejate seksuaalsus ja nende vahelised potentsiaalsed või tegelikud 
seksuaalsuhted. Artiklikogumikus analüüsivad nii mehed kui ka naised, nii hetero- kui ka homoseksuaalsed antropoloogid oma välitöökogemusi. Käsitletakse väga laia spektrit seksi ja seksuaalsusega seotud teemasid - platoonilisest kiindumusest ning heast või kahetsusväärsest seksist kuni hirmutavate vägistamislugudeni. Paljudes artiklites arutletakse välitöödel kohatud Teise ja uurija suhte üle. Seksaalsusega seotud temaatika paljastab välitööliste kahepalgelisuse: ühelt poolt rõhutatakse eduka välitöötegija lähedust tema informandiga, kuid teisalt teevad tekkivad seksuaalsed ihad või suhted nähtavaks antropoloogi ja uuritava vahelised erinevused, klassivahed, rassistlikud eelarvamused ning välitöö hierarhilise loomuse ja võimusuhted. Näiteks Kreekas õigeusklikke palverännakuid uurinud Jill Dubisch kirjeldab, kuidas seksuaalselt laetud situatsioonid ning kaks seksuaalsuhet kreeka meestega panid ta reljeefsemalt nägema välitöö hierarhilisust ja sinna sissekirjutatud võimusuhteid. Kuigi antropoloog oli tekitanud enesele illusiooni lähedusest uuritava kogukonnaga, pani võimalik suhe kohaliku mehega uurija teravdatult mõtlema taustast ja haridusest tingitud klassierinevustele. Seksuaalsuhtesse astumine hirmutas naisantropoloogi esmalt seetõttu, et see oleks võinud rikkuda tema suhted kogukonnaga ning mõjuda hukatuslikult tema uurimustööle. Teisalt mõistis Jill Dubisch, et ta kardab intiimsemaid suhted kreeka meestega ka seetõttu, et sellises suhtes peaks ta loobuma oma ülimuslikust ja privilegeeritud uurijapositsioonist ning alluma oma "uurimisobjektidele", kes paigutaksid ta hierarhiliselt madalasse kohalike meeste poolt võrgutatud Lääne naise kategooriasse (Dubisch 1995, 35, 36). Niisiis on seksitabu üks põhjuseid uurijate soov pidada oma välitööala "puhtana", jääda võimupositsioonile ning hoida distantsi oma informantidega, vaatamata sellele, et oma kirjutistes püütakse tekitada illusiooni piirideta üksteisemõistmisest ja lähedusest.

Jill Dubisch kirjeldab üht valgustuslikku hetke, kui tema välitööperioodil koduks olnud korterisse tuli ootamatult külla meesinformant, kellega uurija oli juba aastaid olnud justkui hea sõber ja peretuttav. Uurija tundis end paljastatuna. Informant oli ühtäkki tema privaatsfääris, uurija polnud nii sündsalt riietatud kui külatänaval ja kirikus, kus nad tavaliselt olid kohtunud, ning tema korteris valitses segadus, mis võis viidata sellele, et tegemist pole hea perenaise ja korraliku naisega. Uurija siiski kogus end kiiresti ning lähtudes kultuurilisest skriptist, palus külalisel istuda ning 
serveeris talle ouzot ja suupisteid. Mees pakkus naisele omakorda sigarette, millest naine ei keeldunud, kuigi tema senine põhimõte oli olnud uuritavas külas suitsetamisest hoidumine. Selle lühikese ja formaalse vestluse käigus sai Jill Dubisch aru, et nii tema ise kui ka tema informant tajuvad esmakordselt pika tutvuse järel üksteist seksuaalsete olenditena. Uurija tundis, et ta kohtles sel hetkel seda kreeka meest võrdsemana kui varem, ning enam sellisel viisil, nagu ta kohtles oma kultuurist pärit mehi. Ja eneselegi üllatuslikult polnud uurija kuni selle hetkeni tajunud, kui suur distants tema ja informandi vahel oli valitsenud (Dubisch 1995, 47).

Vaatamata Don Kulicku ja Margaret Willsoni mingis mõttes väga revolutsioonilise kogumiku ilmumisele pole ka tänapäevane põhivoolu antropoloogia välitöödega seotud seksuaalsust ja seksi puudutavas kuigivõrd avameelsem kui klassikalised tekstid. Siiski on viimasel ajal välitööde ja seksiga seotud teemad sotsiaalmeedias ja ajakirjanduses mõneti tähelepanu pälvinud, kui on käsitletud välitööde läbiviimise uudseid viise tänapäevaste seksiotsimise või tutvumisrakenduste abil. Kui populaarne antropoloogide internetikeskkond Allegra Lab: Anthropology, Law, Art \& World postitas 2017. aastal Anya Evansi artikli "Tinder kui metodoloogiline tööriist”, muutus artikkel viraalseks, seda jagati üllatavalt palju ning see sai tohutult palju tagasisidet (vt Evans 2017b). Lugu sai alguse sellest, et Iisraeli poolt okupeeritud Läänekaldal välitöid tegev antropoloog Anya Evans sai ühel hetkel aru, et talle juba varasemast tuttav tutvumisrakendus Tinder on kõige turvalisem ja lihtsam viis jõuda okupeeritud tsoonis olevate palestiinlaste ja iisraellasteni ning saavutada nendega välitöödeks vajalik "tõeline" kontakt. Tutvumisrakendus võimaldas välismaa uurijal turvaliselt ja enda poolt soovitud viisil navigeerida ruumiliselt ja sotsiaalselt eraldatud kogukondade vahel (palestiinlased, juutidest ja moslemitest Iisraeli kodanikud, Iisraeli sõjaväelased), ilma enese isikule liigset tähelepanu tõmbamata. Anya Evans oli küll kõigiti teadlik sellise suhtlusviisiga seotud võimalikest eetilistest probleemidest, kuid eelistas just turvalisuskaalutlustel Tinderis leitud informante. Tavapärased väljaspool internetti toimuvad välitööd samas piirkonnas olid Evansile kaasa toonud mitmeid ohtlikke olukordi ja ahistamist, millele uurija püüdis reageerida mitte nii teravalt, kui ta oleks teinud oma kodumaal, sest ta kartis süüdistusi ülereageerimises ja kultuuridevahelises kommunikatsioonis ebaõnnestumises. Tutvumisrakenduse pakutav keskkond, kus sotsiaalsed suhted on 
eksperimentaalsemad ja segasemad kui tavaelus, võimaldas uurijale võrdsemat ja turvalisemat tsooni, kus ta jõudis kiiremini isiklike teemadeni, kuid võis samas lihtsalt elimineerida vägivaldseks muutuva või ohtliku suhtluspartneri, ilma et see oleks kahjustanud tema uurimust või reputatsiooni (vt Evans 2017a, 2017b).

Tänapäeval, kui välitööd ei tähenda enam ilmtingimata kaugele rändamist ja võõraid eksootilisi kultuure, ega ka ilmtingimata jäädvustatava ja jäädvustaja suurt vanusevahet, on selge, et välitöödel võib ette tulla lähedust, mis ületab mingi traditsiooniliselt sobivaks või sündsaks peetud piiri. Erinevates kultuurides ja kogukondades on suhtumine teatud earühmadesse või sugupooltesse väga erinev, ning kultuuriliselt määratletud on ka seksuaalsuse erinevad väljendusviisid. Samas on ka uurija sageli koormatud oma eelarvamustest ja hirmudest ega pruugi seetõttu oma empaatilise välitöölise maski taga tõeliselt lähedaste suheteni iialgi jõuda.

Traditsiooniliselt pole folkloristid, etnograafid ja antropoloogid usundit või religioosseid inimesi uurides pidanud vajalikuks avada oma usundilist tausta. Pikka aega on usutud, et "objektiivsuse" tagab uurija distants uuritava suhtes ja võõra pilk ning seetõttu on uurijad ikka uurinud pigem võõraid kui lähedasi. Teiste usundite kirjeldajad ja analüüsijad pole enda konfessionaalset kuuluvust või religioossust paljastanud, sest see pole ilmselt tundunud uurimistulemuste suhtes relevantsena. Teadlaste biograafiaid uurides võib siiski märgata, et nt antropoloogiaklassikud pole olnud sugugi religioonikauged ega usuleiged inimesed (vt Larsen 2016). Arutasin kord refleksiivselt, kuidas uurija religioosne taust mõjutab seda, mida ta väljal saab, ning kuidas klassikalised antropoloogid on oma isiklikku religioosset tausta kiivalt varjanud. Selle peale kirjutas mulle just välitöödelt naasnud homoseksuaalne tuttav, kuidas ta on palju mõelnud sellele, kuidas uurija seksuaalne orientatsioon võiks mõjutada suhtlust väljal ja seda, mida uurija külas kogub. Kolleeg kirjutas oma välitöödel kogetud frustratsioonist, mida ta oli tundnud, varjates kiivalt oma seksuaalset orientatsiooni kogukonnas, mida ta eeldas olevat konservatiivsem kui tema enda kultuur.

Väga õige, huvitav ja vajalik tekst. Meenutab palju mu tööd X rahvaga. ${ }^{2}$ Lisaks nendele aspektidele on tähtis muidugi ka uurija orientatsioon. Ma pole suurem päeviku pidaja, aga välitöödel kirjutan-ja see isegi meeldib. Mäletan hästi poolteist aastat tagasi $X$ külas, kui öösel kirjutama hakkasin. Meil oli olnud paar huvitavat päeva, palju

${ }^{2}$ Tekst on avaldatud kirjutaja nõusolekul ja anonümiseeritud minu poolt. 
kohalikke, suhtlust nende keeles, surnuaiapüha jne. Lahke naaber kutsus sauna ja kuna olin ainus meesterahvas, läksin sinna juba varem ja olin saunas perepojaga (noh, nii 35 a). Ta enam eriti X keelt ei rääkinud ja mu Y keel on liiga kehv, kummaline, aga suhtlesime $Z$ keeles. Olukord oli kuidagi põnev, isegi erootiline. Ma ei tea, mis mõttes ma teda huvitasin, võibolla ainult kui eksootiline võõras, kes tahab tema pere ja küla asju teada saada, aga kes teab, äkki rohkemgi. Ta oli hea peremehe eest, aga kaua me seal ei olnud. Naised juba ootasid õues. Pärast läksin üksi naabri pööningule väiksesse tuppa, kus elasime, ja kirjutasin, kui pettunud ma endas olen. Millises rollis (vallaline, rõõmus, heteromees) ma välitöövestlustel olen. See mõjutab ka teaduslikku poolt. Eeldan, et inimesed mulle ei valeta, aga samas valetan ma pidevalt neile.

Kuidas saaks seksuaalne orientatsioon olla vähem tähtis kui Siikala järgi perinneorientaatio, mida võtan arvesse ja mille järgi suunan oma välitöid. Tean väga hästi, et mul on kalduvus olla aktiivne ja läheistävä kertoja ${ }^{3}$ ja ei tee sellest saladust. Aga miks ma ikka veel selles vanuses ei suhtle just nt külas omavanuste meestega, kelle poole on isegi mingi tõmme, vaid käitun kummaliselt? (Erakirjast, 05.05.2014)

\section{Kosjajutud ja "kupeldamised" kui normaalne suhtlus välitöödel?}

Kui uurisin Armas Otto Väisäneni välitöid Setomaal ${ }^{4}$, panin tähele, et Väisäneni mälestustes on kuidagi ootamatult esil just sugupoolte vahelisi suhteid puudutavad arusaamatused, mida uurija ja uuritavate erinev kultuuritaust põhjustasid. Väisänen oli välitöid alustades vallaline mees, ning oletasin, et just see seik tegi seksuaalsusega seotud teemad ja kosjajutud aktuaalseks (vt Kalkun 2015). Väisäneni mälestustes tulevad aina esile erinevate rahvaste juures kogetud kummalised sugude-vahelise suhtlemisega seotud juhtumised (nt vepsa tüdruku "taltsutamine" suudlustega, vt Väisänen 1969) ning korduvad olukorrad, kus noorele uurijale taheti leida abikaasat, pruuti või lihtsalt pakuti neiut, kelle kõrval võiks öö

${ }^{3}$ Anna Leena Siikala jagas oma jutustajate tüpoloogias inimesi nende pärimusorientatsiooni järgi etäistävä ja läheistävä jutustaja, millest esimene on enam distantseeritud oma jutustatavatest lugudest ja teine eelistab neid siduda oma elu ja kogemustega (Siikala 1984, 167).

${ }^{4}$ Väisänen käis Setomaal välitöödel kuuel aastal, esimest korda 1912. aastal ja viimast korda 1924. aastal. 
veeta. Väisänen olevat oma välitöödel suutnud inimestega kergesti kontakti leida, mõnede laulikutega tekkis uurijal aastaid kestnud lähedane suhtlus. Mõningaid vanemaid naisinformante olevat nii Väisänen ise kui ka tema uuritavad kogukonnad naljatades tema pruutideks kutsunud.

Enne Väisäneni Setomaa välitöid peatus ta Pihkvas, kus teda olevat tahetud paari panna kindrali tütre Maria Vladislavnaga (1970, 19, 20). Seejärel meenutab Väisänen oma mälestustes lahkeid seto külanoorukeid, kes innustasid ööseks tüdrukute juurde minema; lõõtsamängijat, kes pani öömaja küsija oma tütre kõrvale magama ning kahte venda, kes ei pahandanud, kui Väisänen ööbis nende õe juures. Setomaa välitöödega seoses meenutab Väisänen veel, kuidas teda Setomaal rahvatantsu-uurija Anna Raudkatsiga ühe kasuka alla magama taheti panna ning kuidas seto perenaine vihastas, saades kuulda, et Anna ja Armas Otto magavad eraldi. Kena naljaloona jutustab Väisänen, kuidas ta kord noore mehena mänginud seto neiule kosja minekut, et öömajale saada. ${ }^{5}$ Lisaks kirjeldab Väisänen oma mälestustes Setomaad eksootilise maana, kus peetakse viisakaks ja auväärseks žestiks, kui noormehele tehakse ööase kohaliku neiu kõrvale. Väisänen meenutab üht dialoogi kauni seto neiuga, kelle vennad olevat lahkelt palunud külalise oma õe kõrvale magama. Väisänen olevat küsinud neiult sängis: "Kas see pole ohtlik naisele, kui mees tuleb kõrvale magama? Te naised ju saate aru küll, mis tunded meestes ärkavad?" Mille peale neiu olevat vastanud: "Küll me juba teame, ära õpeta mind. Proovi vaid, saad näha, kuidas läheb" (Väisänen 1970, 27).

Väisänenile oli seto kultuuris tavaline noorte öine koosmagamise komme ilmselt midagi väga võõrast ja irratsionaalset, samuti on ta šokeeritud seto neidude "liigsest" aktiivsusest ja talle võõrastest käitumismudelitest. Krantsova külas olevat neiud palunud Väisänenil ööseks nende juurde tulla ning öise külastuse lootuses olevat nad leppinud isegi sellega, et laulupalgaks olid vaid maiustused.

Krantsovalased osutusid eriliseks rahvaks. Ehk tulenes see sellest, et polnud ühtki poissmeest. Ju siis seetõttu andsidki tüdrukud märku, et oleksin olnud läinud ööl väga teretulnud nende mano tulles. Nad laulsid isuga ja ei nõudnud lisaks mu antud kompvekkidele muud midagi. Kahju, et neist pidi kiiresti lahkuma. Nad olid kiirustamas

5 Samadest "mängukosjadest" jutustas Väisänen Helsingin Sanomate lugejale juba 1921. aastal (vt Väisänen 1992, 113). 
lähedal peetavasse pulma ja kutsusid mindki kaasa, kuid olin otsustanud minna otse Luhamaale. (Väisänen 1992, 21)

1913. aasta reisipäevikus kirjutab Väisänen ka sellest, kuidas seto neidude vanemad olevat Väisänenile teinud ettepanekuid võtta tütar ära või jääda vähemalt öömajale. Näiteks Kiiova külas taluperemees Sido Nikiti pillimängu salvestamise järel olevat pakutud Väisänenile süüa ja viina ning perenaine küsinud, et ega võõras ei tahaks öömajale jääda, sest majas on kaunis tütar.

Kui sõin, mainis perenaine, et kas mul poleks isu öömajale jääda, kui Nati koju tuleks: "Mul on kaunis tütar". Peagi tuligi see koju. Tõesti lopsakas tüdruk: väärikas kuju ja keha, millel siiski puudus oilis rüht. Seletuse sellele annabki seik, et tüdrukul tuli palju üleval olla. Isa kasutab tüdruku külgetõmbavat välimust ära: mü̈̈b viina noortele meestele, kes tüdruku mano tulevad ning joob nendega; poisse käibki küllaltki tihti. (Väisänen 1992, 8, 9)

Tähelepanuväärselt näeb Väisänen seto neiude ilu ja olekut millegi poolest ebatäiuslikuna ning võtab neid pakkumisi kui eksootilisi kurioosumeid. Võõristus tuleb veelgi selgemini esile Helsingin Sanomate lisalehes avaldatud setode kombeid tutvustavas artiklite sarjas. Selles kirjutises kõrvutab Väisänen seto neidusid ja nende loomust ja moraali "Kalevala" müütiliste naiskangelastega, aga ka Karjala laulukülade idealiseeritud neidudega ning leiab, et seto neidude teistsugune seksuaalmoraal on jätnud ka nende tundeelule mingi pitseri, mistõttu setod ei küündi teatud tundepeensusteni.

Tõuseb küsimus, kas seto noorsoo suhteid võiks võrrelda Lemminkäise mängudega Saare neidude hulgas. Tõenäoline tundub, et Lemminkäiseid on Setomaal palju, Kyllikkeid vähe. Külma statistika järgi asja kontrollides pole küll põhjust süüdistada setosid erakordselt halvas seksuaalmoraalis. Sellised suhted on aga siiski mõjutanud neidude tundeelu, kus puuduvad need ornad varjundid, millest räägib "Kalevala" laul Ainost. [---] Teisiti on lugu Kalevala laulumaal. Iga sealkäinu räägib vaimustusega Viena Karjala neiust; viitan vaid Inha ja Kianno kirjeldustele. [---] Siiski on kokkulepe nende vahel, et iga neid on vaid ühe jaoks, ja kelle jaoks, see selgub sageli alles kosjade ajal. Neiu, kes on rikkunud noorte suhtlemise tavasid, mille hulka ei kuulu öised kohtumised, ei sobi enam neitside rõómsasse seltskonda. (Väisänen 1992, 112, 113)

See, mismoodi ajalooliselt on setode seksuaalmoraali ja neiude tundepeenust või selle puudumist representeeritud, on sõltunud 
ilmselgelt tõlgendaja eesmärkidest ja taustast. Väisäneni kirjutised toetuvad võõrmõjusid halvustava ja rahva "algset" loomust idealiseerivale ideoloogiale. Karealistlikust taustast tulenevalt on Väisäneni jaoks kõlbelisust ja seksuaalmoraali puudutavate ideaalide varjupaik Karjalas ning seetõttu ei ole tal põhjust kujutada setosid ja nende armuelu karjalaliku või täiuslikuna. Kuigi Väisäneni suhted setodega olid soojad ning ta jõudis setodele lähemale, kui varem ükski välitööde tegija oli jõudnud ${ }^{6}$, olid kultuurist ja haridusest tulenevad erinevused ja eelarvamused nii suured, et see lähedus, mida setod pakkusid, ei saanud kõne allagi tulla.

Esmakordselt Väisäneni mälestuslikke tekste ja välitööpäevikuid lugedes tundusid Väisäneni rohked kosjalood natuke ootamatud ja arusaamatud. Kuid ühel hetkel sain aru, et need mälestused ei erine oluliselt minu enda samalaadsetest kogemustest. Jah, alates esimestest välitöödest oli minu käest nii Setomaal kui Siberis lugematuid kordi uuritud, kas mul pruuti on, vihjatud sellele, et ju ma käin ringi eesmärgil leida pruut, lubatud mind tutvustada mõnele kohalikule neiule (enamasti oma lähisugulasele) ning soovitatud kohti, kus noored omavahel võiksid tutvuda. Seda on juhtunud nii esmakohtumistel, kui ka inimestega, keda olen aastate jooksul korduvalt külastanud. Minu käest on korduvalt pinnitud, ega ma oma suhteseisu kohta valeta, tuttavamad on küsinud, miks ma parasjagu suhtes pole või miks ma olen parasjagu üksi. Naljatledes on ähvardatud, et kui järgmine aasta tagasi tuled, olgu siis pruut kaasas, "muidu kaeme siist sullõ mõnõ hüä naase".

Olen ilmselt ajapikku harjunud, et minu poolt uuritavates kogukondades kuulub selliste teemade üle arutamine suhtluse juurde. Ilmselt minu informantide põlvnemine traditsioonilistest agraarsetest kogukondadest ning meie vanusevahe (vanema targa inimese ja "kogenematu nooruki" suhe) on andnud sellisteks vestlusteks omakorda põhjust. Kuigi väljaspool välitöösituatsiooni ei peaks ma selliseid küsimusi ilmselt sobivateks, pole ma välitööl neid küsimusi

${ }^{6}$ Väisäneni väga hea seto keele oskuse ja olude tundmise tõttu suutis ta seto naistele nii lähedaseks saada, et 1922. ja 1923. aasta välitööde tulemusel valmis artikkel "Syntymä, lapsuus ja kuolema. Setukaisten tapoja ja uskomuksia”, kus käsitleti muuhulgas mitmeid tabuteemasid. Obinitsa koolimajas küsitletud Miko Ode ja Treiali Ode andsid Väisänenile küllaltki ainulaadset ja intiimset teavet seto naiste menstruatsiooniga seotud tabude ja uskumuste kohta, aga ka abielueelsete suhete, armumaagia jms kohta, vt Väisänen 1924. 
kunagi eriti südamesse võtnud, kuna olen sageli oma vestluspartneritelt ka ise häbenedes ja häbenemata küsinud väga intiimsete ja tabustatud teemade kohta (nt menstruatsiooniga seotud jutud, aga ka intiimseid religioosseid või üleloomulikke kogemusi puudutav). Niisiis olen võtnud neid pruudi-jutte kui paratamatut osa dialoogist. Olen uskunud, et see, et mu vestluspartnerid muretsevad mu suhtestaatuse või seksuaalsete vajaduste rahuldamise pärast, näitab, et nad hoolivad minust ning meie suhe on jõudnud tasemele, kus sellistest teemadest võib rääkida.

\section{Tabude piirid ja uurija piiratus}

Minu käest on sageli küsitud, miks ma ei uuri meeste laule ja meeste usundit. Miks peaks üks mees uurima naisi puudutavaid teemasid, liiatigi asju, millest pole seto kultuuris kombeks avalikult rääkida? Olen uurinud seto pärimust, eelkõige vanemat laulupärimust ja setode õigeusutõlgendusi. Kuna seto naistelt on kirjutatud üles ja helisalvestatud kordades rohkem laule kui meestelt, olen tegelenud just naiste lauludega. Samamoodi, kuna seto naised on tänapäeval religioosselt aktiivsemad (juba 19. sajandi lõpus oli see nii), olen uurinud just naiste usundit. Patriarhaalses seto külas moderniseerusid mehed koduseinte vahele suletud naistest palju varem, ning sellest tulenevalt on täna just naised need, kelle side mineviku ja oma pärimusega on palju orgaanilisem ja tugevam kui seto meestel.

Olengi neist eelnevaist põhjustest ning kindlasti ka külades valitsevast demograafilisest olukorrast ja oma eelarvamustest tulenevalt vestelnud kordades rohkem naiste kui meestega. Kõik minu "lemmikinformandid" on olnud naised ning kõige soojemad suhted ja pikaajalisemad koostööd väljal on seotud just vanemate seto naistega. Samas olen siiski korduvalt kogenud, kuidas minu eelarvamused selle kohta, mida teatud vanuses mehe või naisega saab rääkida, pole olnud põhjendatud. Välitöödel kulub alati uue inimesega tutvumiseks teatud aeg, mil saab enam-vähem aimu, mis teemadel on võimalik vestelda ning milline dünaamika vestlejate vahel kujuneb, aga kontakti või üksteisemõistmist ei pruugigi sündida.

2010. aasta välitöödel Petserimaal saime teada, et Gagarina külas elab umbes 60aastane seto mees. Olime selles piirkonnas ka varem välitöid teinud, kuid Gagarina külla polnud varem sattunud, sest olime kuulnud, et seal pole elanikke. Kuna tahtsime küla 
näha, läksime juhatust mööda kinnikasvanud teid pidi küla otsima. Kohalikud hoiatasid, et Nikolai Hank elab majas, mida me võib-olla elumajaks ei pea, ja see vastaski enam-vähem tõele. Mees oli nõus rääkima, ta istus oma onni lävele ja meie tema jalge ette. Rääkisime Gagarina külast ning tema lapsepõlvest, siis sellest, kuidas ta oli käinud tehnikumis ja töötanud ühes Viljandimaa kolhoosis. Rääkisime elust “sisemaal” ja kodusel Setomaal, Nikolai abieludest, naistest ja pojast. Püüdsin empaatiliselt kaasa vestelda ka laudatehnikat või traktoreid puudutavas. Mingitel spetsiifilisematel usundit ja kombestikku puudutavatel või vanema elu-oluga seotud teemadel vestlemine, tema sugu, vanust ja tausta silmas pidades, ei tundunud relevantne. Vaatamata tema n-ö noorusele, pikale külast eemal olemisele ja mingis mõttes modernsusele, selgus siiski, et tal on kogemusi, mida paljudel temaealistel naistelgi polnud. Tähelepaneliku lapsena oli ta nimelt salaja külanaise sünnitust pealt vaadanud ning oskas üsna detailselt kirjeldada, mismoodi Gagarina küla "krundi peal" olevas talus tema lapsepõlves sünnitusabi anti. Minu juhuslik ja õnnetu küsimus kodusünnituste kohta tuletas talle meelde lapsepõlves nähtu ja Nikolai jutustas meile sünnitusest sellise detailsusega, mida poleks temaealiselt mehelt oodatagi osanud.

Mina: Innepidi ju kotoh sünnütedi kah, kes sis avitiva’?

Nikolai: Jajaa, jajaa, ma eiski mälehtä tuud, pilost õks kai tuud asja... lätsi ütskõrd imäga, pilost kaie. [---] Sis olli taa, imäga lätsi, et läämi sinnä’ krundi pääle, kilomeetri maad. Lätsi sinnä ja, aga tuul tuhu' pääl. Miist ei olõ' kotoh, sääl paar tüdrukut sis jah. Ja sis imä juus'k sis küllä, sääl tuul oll' määne katõssa-ütessä sünnütüst jo olnu, täl õks kogõmusõ' omma'. Tuu tull' sinnä' ja, mi säält pilost kaimi tuud asja kõgõ. Mis asi sääl k'au. Tä oll' sis rõivist vallalõ võetu ja olõ' oll" maaha pantu. Ja olõtuustaga tuu pand' sis, tasosi sälgä. Ja kuis tuu asi sis käve.

Mina: A tuu süntäjä oll' sis sällülde vai kõtuldõ, käpilde?

Nikolai: Käterätt oll' pantu sängüjala külge niimuudu ülest ja tuu ütel', et kisu' käterätist! Ja tuu sis kiske käterätist, aga tuul oll' sis jah linast vai olõst kääntü taa ja tuuga lask' sälgä müüdä.

Mina: Sälgä mü̈̈dä?

Nikolai: Ma nii pall'o säält pilost kai, a meid õks säält kõrraga ar aeti. Imä saiś kah sääl sängü veereh ja. Ha-ha-ha. A mi õks tüdrukidõga vahemi pilost sääl. No mis, mulgi naisterahvas siin sünnüt, kooni ma kutsõ kiirabi, tuu ütel', et Pankjavitsa om lännü ar'a, kooni tuu 


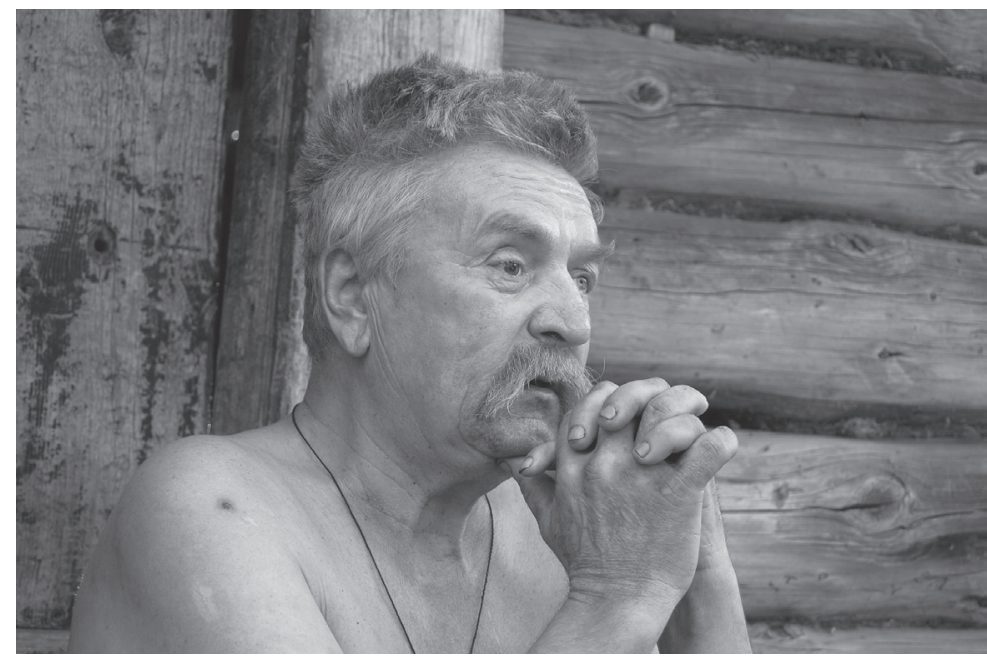

Nikolai Hank oma naisega olid 2010. aastal Gagarina küla ainsad elanikud. Gagarina küla, Petserimaa. Foto: Tiit Sibul.

Pankjavitsast tull', koon ma oodi Sokolovah sääl nulga pääl ja teie suitso, Taro-vanamutt oll' siih ja istsõ joba, kõik kõrrah joba. ${ }^{7}$

(TÜ EMSA, DS0091-04 < Pihkva obl, Petseri raj, Gagarina k Andreas Kalkun, Tiit Sibul < Nikolai Hank, snd 1950 (27. juuli 2010))

${ }^{7}$ Mina: Varem ju kodus sünnitati ka, kes siis aitasid? Nikolai: Jaa, jaa, ma isegi mäletan seda, ikka pilust vaatasin seda asja... läksime ükskord emaga, siis vaatasin pilust. [---] Siis oli see, emaga läksime, et lähme sinna krundi peale, kilomeeter maad siit. Läksime sinna, aga sellel [perenaisel] olid tuhud peal. Meest polnud kodus, seal paar tüdrukut oli siis jah. Ja siis ema jooksis külla, seal ühel oli mingi kaheksa-üheksa sünnitust juba olnud, et sellel ikka kogemused on. See tuli sinna ja me siis sealt pilust vaatasime seda asja kogu aeg. Et mis asi seal käib. Ta oli siis riidest lahti võetud ja õled olid maha pandud. Ja õletuustiga see pani siis, masseeris selga. Ja kuidas see asi siis käis. Mina: Aga see sünnitaja oli siis selili või kõhuli, käpuli? Nikolai: Käterätt oli pandud voodijala külge niimoodi üles ja see ütles, et kisu käterätist! Ja too siis kiskus käterätist, aga sellel oli siis jah linast või õlest keeratud see ja sellega ta lasi selga mööda. Mina: Selga mööda? Nikolai: Ma niipalju sealt pilust vaatasin, aga meid ikka sealt korraga aeti ära. Ema seisis ka seal voodi ääres. Ha-ha-ha. Aga meie ikka tüdrukutega vahtisime sealt pilust. No mis, mulgi abikaasa siin sünnitas, seni kui ma kutsusin kiirabi, see ütles, et Pankjavitsa on läinud, kuni see Pankjavitsast tuli, kuni ma ootasin Sokolovas seal nurga peal ja tegin suitsu, Taro-vanamutt oli siin ja istus juba, kõik korras juba. 
Olen välitöödel uurinud naisi, kellega koos olen kirikus laulnud, ma olen nendega koos trüginud ristikäigus, oodanud armulaua või ristile suuandmise järjekorras. Nad on pakkunud mulle kommi oma lahkunute mälestuseks ja kiitnud minu lauluhäält. Kuna olen õigeusklik, siis usun, et meil on mõningaid sarnaseid kogemusi, ma kujutan umbes ette, mis tundeid või mõtteid mingi rituaalne praktika tekitab. Teame, mis tunne on laulda tühja kõhuga kaks tundi või rohkem kestval liturgial, paastuda, suudelda ikooni, risti või preestri kätt, teha maani kummardust või tungelda ristikäigus.

Samas, kui ma olen istunud nende naistega nende kodus ja küsinud nagu muuseas: "Kas om määnegi aig, ku naane tohi-i kerikohe minnä'" " siis ma olen olnud selgelt uurija, kes ei istu lahtiste kaartidega, vaid kavaldab, et teada saada, mida see naine teab kirikuga seotud menstruatsioonitabude kohta (vt Kalkun 2007). Ma tean, et arhiivis on õigeusklike naiste piirangutest kõnelevaid tekste, ma olen seda küsimust juba kümnete naiste käest küsinud, ma tean nende tabude teoloogilisi põhjendusi ja kirjakohti, millele need tuginevad. Aga sel hetkel on mul välitööde huvides lihtsam mitte avada neid taustu, et saada teada, kuidas see konkreetne naine neist asjust räägib.

Niisiis, kuigi võin olla nende naistega lähedane, olla nendega dialoogis, jagada sarnast päritolu või religioosset tausta, juhtub ikka, et olen välitöösituatsioonis hegemoonilisel positsioonil uurija, kellel on lihtsam mitte pühendada oma vestluspartnerit kõigesse toimuvasse. Sellised näiliselt süütud ja naljakad küsimused on mingis mõttes võtmed või muukrauad, mis peaksid minu kui uurija jaoks avama ukse mingite mulle huvi pakkuvate teemadeni jõudmiseks. Ja muidugi olen teadlik, et need teemad võivad informandile olla potentsiaalselt ebameeldivad või ebamugavust tekitavad. Sellised salakavalad küsimused on justkui "söödad" või "lõksud", millele vastamine võib viia soovitud teemadeni. Teoloog Elina Vuola on kirjutanud, kuidas katoliiklike naistega Neitsi Mariast rääkimine on justkui uks, mis avab Pandora laeka, kus on sees kõik arutelud, mis puudutavad naise keha, seksuaalsust, emadust, aga ka kriitikat kirikuelu, ametliku teoloogia või kitsamalt marioloogia suhtes (vt nt Kalkun \& Vuola 2017). Samamoodi on minu välitöödel mõned esmapilgul naeruväärsed küsimused näiteks vanaema aluspükste kohta pannud informandi arutama naise elu ja seksuaalsust puudutavate

${ }^{8}$ Kas on mingi aeg, kui naine ei tohi kirikusse minna? 
teemade üle nii ajaloos kui ka kaasajal, ning olnud peaaegu otseteed teemadeni, kuhu muul viisil on keeruline jõuda.

Kuigi me võime eeldada, et folkloristid väljal on oma informantidest avatumad, võib elu ette tuua situatsioone, mis paljastavad uurija eelarvamusi, tema piiratust ning tema kultuuris kehtivaid tabusid. Enamasti on uurijad need, kes initsieerivad situatsioone ja vestlusi, mis ei pruugi olla vestluspartnerile kõige mugavamad või tavalisemad. Kuid et välitööd on oma loomult dialoogilised, peab ka uurija olema valmis teemadeks, milles ta ennast koduselt või turvaliselt ei tunne.

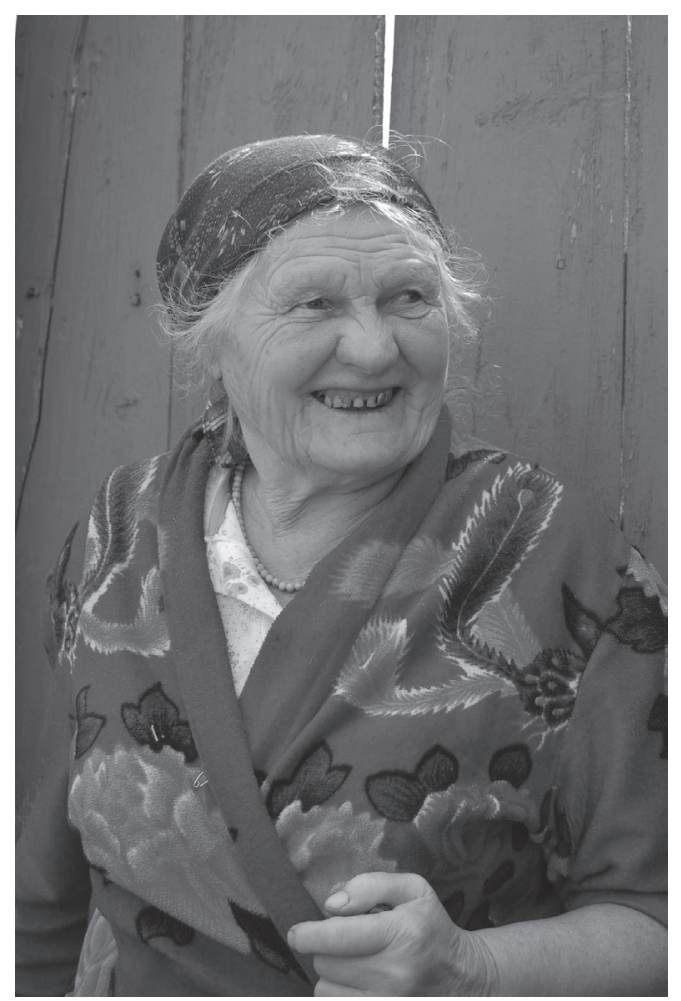

Väga hea pärimuse tundja ja jutustaja Maria Jeremejeva 2008. aastal, kui teda pärast aastast pausi taaskülastasime. Krestjanski küla, Krasnojarski krai. Foto: Tiit Sibul. 
Välitöödel Siberisse emigreerunud setode järeltulijate juures külastasime koos Anu Korbiga korduvalt (2007, 2008, 2012) väga head jutustajat Maria Jeremejevat (1934-2013) Krestjanski külas ${ }^{9}$. Manni oli väga hea mäluga ja tähelepanelik inimene, kellel oli imeline oskus lugusid jutustada. Ta oli inimene nagu folkloristi unistus: iga märksõna, mille õhku viskasime, seostus tal mingi looga tema enda elust või mõne tema esivanema või tuttavaga seotud narratiiviga. Empaatiliselt kuulas ta meie imelikke ja tavalisemaid küsimusi ning jagas hea meelega lugusid, mida meie märksõnad talle meelde tuletasid. Muidugi küsisin muuhulgas ka vanaema aluspükse ja menstruatsioonitabusid puudutavaid küsimusi. Manni rääkiski meile mitmel korral lugu, kuidas ta oli lühikest kasvu noore plikana nii rumal, et arvas, et on end suurte kangastelgedega kududes ära venitanud, kui esimene menstruatsioon algas. Manni ema oli varakult surnud ja keegi polnud talle menstruatsioonist rääkinud, niisiis oli Manni veendunud, et ta on oma agarusega end ära vigastanud, olles vaatamata vanemate inimeste keelule liiga usinalt kudunud. Loomulikult küsisin ka hügieenisidemete ja muud hügieeni puudutava kohta ning puudutasime oma vestlustes ka palju muid teemasid, mille üle igapäevaselt võõraste meeste ja naistega üldjuhul ei arutata. Meie viimasel kohtumisel 2012. aastal oli Manni tütar ema külast Krasnojarski linna enda juurde elama toonud. Manni, kes oli aastaid külas üksi loomi pidanud ja oma majapidamist juhtinud, oli nüüd justkui suletud tohutu suurde paneelmajja. Manni rõõmustas, et me olime ta üles leidnud ja meiegi rõõmustasime, veetsime mõnusalt koos aega ning salvestasime tundide kaupa vestlusi kõige erinevamatel teemadel. Muuhulgas rääkisime Manni vanaemast, kes oli külas sünnitusi vastu võtnud ja surnuid pesnud. Surnu juurde oli mõnikord laps ühes võetud, aga sünnituse juurde mitte kunagi. Nagu Nikolai Hangil, nii oli ka Mannil siiski kogemus sellest, kuidas ta oli piilunud uudishimuliku lapsena, kuidas tema varasurnud ema sünnitas. Küsisime igasuguseid naljakaid täpsustavaid küsimusi ja Manni oli detailne, rääkis, kuidas sünnitamine oli toimunud eesriide varjus ja põrandal õlgede peal. Küsisin, mis tehti perämiste ehk platsentaga ning Manni rääkis, mis teadis. Siis jõudsime laste tuleviku ennustamise juurest tema enda sünnitusteni ning uurisin sünnitusjärgse käitumise ja tarõnaist puudutavate keeldude kohta.

9 2008. aastal osalesid vestluses ka Tiit Sibul ja Astrid Tuisk. 
Seejärel juhtus ettenägematu asi, Manni puudutas meditsiinilist teemat, millest ma polnud kuni selle hetkeni ühegi naise ega mehega rääkinud. Sel hetkel tundus see Manni jutukäänak väga ootamatuna ja millegipärast täiesti kohatuna, nii et ma polnud võimeline ei mõistlikke täpsustavaid või lisaküsimusi küsima, ega teemat jätkama. Imestasin juba sealsamas oma ägeda vastureaktsiooni üle ning püüdsin kõigiti oma kimbatust varjata. Pärast tohutu pikana tunduvat imelikku pausi küsisin järgmiseks selgelt "neutraalsemaid" küsimusi saunasõnade ja muude saunas käimisega seotud rituaalide kohta. Nüüd, aastaid hiljem, seda vestlust uuesti kuulates, sain aru, et salvestisele pole minu kimbatus siiski erilisi märke jätnud. Mälestustes väga pikana tundunud Manni jutt ongi pigem napp ning minu pausidki on täiesti tavalise pikkusega.

Mina: A ku naane oll' nulganaane, kas oll' ka midägi, et tohi-s tetä'? Tarõst tohtsõ vällä minnä??

Manni: No kävevä', kävevä’ vällä õks!

Mina: Külä pääle ôks lä̈̈-s.

Manni: Es, küläh k'au-s. Ma tiiä-i, jäi sis ku kavvani, et nä tohi-s moro päältki vällä minnä’. Tuud tiiä-i tožõõi. Vot õnnõ vanaimä ütel', et ku noorõst, ku pääle latsõ, et kässi nõstku-i ülest korgõbat pääd ei, et vanaimä tuu pääle latsõ... no inne oll' eis küdsivä' leibä tožõ, nuu kvašnjaa' olliva' tože suurõ', ni nõst' tuud vaśnat sinnä aho pääle ni nõst' arki iho. I vot, sis täl käve iho vällä. Vot, sis tä oll' vana jo', i tä õks kõgõ käsk', et noh, viho' sälgä. No vot sis vihõ sägä ni koh oll' määne natirala, natirala. I kõgõ timä ütel': "Kaegõ', lasku-i sinnä' tsorri õi'?" No i, a ma jal mõtlõ, määnes tuu tsori om. No i kuis ma kai alla, ni kae, paabal sääne nii vai munakõnõ sääl. Mõtlõ, et kuis, ot poisil ommava' naa', et mis naistõrahval. A vot sääne viil olli, oi küll ma olli, kuis viil üteldä', nudrets, $i$ oll' vaja kumpi kah, kas pehmekene om vai. A tä jo iho käve vällä täl ni kuivi ar, ar kuionu, kui üldä’ki, ku määne ar kuionu fruktõ, gruša kuionu. Vot ma sis paabalõ ütli, et paaba, mis sul śoo om? "Kull'a latsõkõnõ vot śoo om śoo, et pääle latsõ nõsti taad vaśnat aho pääle ja vot tull' imäkodo vällä ja vot nii jäigi inne. Noh, olõ-s naverna tohtrit ja niisma ka rohitsa-s. I vot i mul jäigi śoo. Õt ti kaegõ', et ku mehele läät, ti nõstu-i korgõba pääd midägi ei.”

Mina: A sa ollit tuud aigu lats sis viil? Kui tuu... 
Manni: No kanešna! Vot ma ummile ka nü̈̈d vnutškilõ kah, et ku sünnütämä läät, smotrite ne podnimaite ruki võše golovo. Hot'o óks om sääne, et massinaga mõskva', ütskõik nöörä pääle vaja panda'. Et smatrite! Ja tõmmakõ'i ho õks kinni kõgõ, kästi. Et tõmmada'minga'

Mina: Ahah! Sis pääle latsõ saamist?

Manni: Nooh! Ja õt kuus nädälit, et tekku-i midägi ja kohegi ni $k^{\prime}$ augu-i. Nü̈̈d usu-i kiaki midägi. ${ }^{10}$

(ERA, DH 425 (13) < Krasnojarski l < Krasnojarski krai, Partisanski raj, Krestjanski k < Vassiljevka k - Andreas Kalkun, Anu Korb $<$ Maria Jeremejeva, kutsutakse Kirilä Manni, Pirko Manni, ristitud Marina, snd 1934 (5. mai 2012))

${ }^{10}$ Mina: Aga kui naine oli nurganaine, kas oli ka midagi, et ei tohtinud teha? Kas toast võis välja minna? Manni: No käisid, käisid välja ikka! Mina: Küla peale ikka ei läinud? Manni: Ei, külas ei käinud. Ma ei tea, kui kaua siis pidi jääma, et nad ei tohtinud õuestki välja minna. Seda ma ka ei tea. Ainult vanaema ütles, et kui noor olin, et pärast lapse [saamist], et käsi ärge tõstke üles peast kõrgemale, et vanaema ise, see pärast lapse [saamist]... no enne oli ju nii, et ise küpsetasid leiva ka, need leivakünad olid ka suured, ja tõstis seda leivaküna sinna ahju peale ja tõstis äragi oma ihu. Ja vot siis tal käis ihu välja. Vot siis ta oli juba vana ja ta alati käskis, et noh, vihu selga. No vot siis vihtusin ta selga ja pesin, kust oli vaja. Ja alati ta ütles: "Vaadake, et te sinna renni ei lase!" No ja mina jälle mõtlen, et milline see renn veel on. No jah, ei tea, kuidas ma vaatasin alla, ja näen, vanaemal on selline munakene seal. Mõtlen, et kuidas, et poistel on need, et miks naisterahval. Aga vot selline veel olin, oi ma olin küll üks, kuidas veel öelda, tarkpea, oli vaja katsuda, et kas on pehme. Aga tal ju ihu käis välja ja kuivas ära, ära kuivanud, kuidas öeldagi, nagu mingi ära kuivanud puuvili, kuivanud pirn. Vot ma siis vanaemale ütlesin, et vanaema, mis sul see on? "Kulla lapsekene, see on see, et pärast lapse sünnitamist tõstsin seda leivaküna ahju peale ja vot, tuli emakoda välja ja vot jäigi nii ainult. Noh, polnud arvatavasti tohtreid ja niisama ka ei ravitud. Ja vot mulle jäigi see. Et te vaadake, et kui mehele lähete, te ärge tõstke midagi kõrgemale oma peast." Mina: Aga sa olid sel ajal laps veel? Kui see... Manni: No muidugi! Vot ma omadele ka nüüd lapselastele [ütlen], et kui sünnitama lähete, vaadake, et ei tõsta käsi kõrgemale peast. Kuigi on selline [aeg], et masinaga pesevad, ükskõik on vaja nöörile [kuivama] panna. Et vaadake! Ja tõmmake ihu ikka kinni alati, kästi. Et tõmmata millegagi [kinni]. Mina: Ahah! Et siis pärast lapse saamist? Manni: Nojah! Ja kuus nädalat, et ära tee midagi ja kuhugi ära mine. Nüüd ei usu keegi midagi. 
Manni rääkis oma vanaema günekoloogilisest songast (tupe või emaka allavaje ehk vaagnaelundite prolaps), mis iseenesest on väga tavaline vanemate naiste kaebus. ${ }^{11}$ Nähtavasti oli Manni rääkinud seda lugu ka oma noorematele naissugulastele hoiatusloona, ning et meil oli eelnevalt juttu olnud tema vanaemast, sünnitusest ja sünnitusjärgsest käitumisest, pidas ta seda sobivaks jutujätkuks. Kuna me olime ka varem Manniga vestelnud teemadel, mida tavaliselt seto külas mehed ja naised koos ei aruta, siis ilmselt uskus Manni, et ka vanaema prolapsi lugu võiks meile huvi pakkuda. Lugu oligi huvitav, kuid kutsus minus esile mulle endalegi ootamatu vastureaktsiooni. Ilmselt ületas see lugu tol hetkel minu jaoks mingi minu kultuuris tabuga seotud piiri, kus ühele poole jäävad huvipakkuvad folkloori, rahvameditsiini, etnograafia, ajaloo ja olustikuga seotud teemad ning teisele poole mingid meditsiinilised nähtused või isiklikud anatoomilised eripärad, millest pole sobilik rääkida. Püüdsin oma kimbatust küll varjata, kuid ootamatult oli minul seekord piir kiiremini ette tulnud kui informandil. Vestlus Krasnojarski linna ühes paneelmajade rajoonis paljastas mulle eneselegi teadmatud tabud, mis peegeldasid ilmselt minule kodust ühiskonda, kus menstruatsioonist rääkimisest veel ebasobivam on menopausijärgse naise kehast ja seksuaalsusest või teatud meditsiinilistest seisunditest rääkimine.

Ma ei tea, kuidas tundis end selle vestluse kolmas osapool, minu kolleeg folklorist Anu Korb, kuid võimalik, et see ebamugavus, mida teravalt tundsin, oligi seotud vaid minu soo ja vanusega. Hiljem leidsin, et ka Hella Keem on oma murdekogumisretkedel rääkinud seto naistega nendelsamadel menopausijärgset naiste tervist puudutavatel teemadel ning informantide lauseid on hiljem kasutatud näidetena sõnaraamatuski: sõsaral käü imäkäss `vällä kõó, imäkoda vai imäkäss Se (VVMS 2011, 129).

${ }^{11}$ USA-s tehtud Women's Health Initiative (WHI) uuringu järgi esineb erineva raskusastmega vaagnapõhja prolapsi $40 \%$ menopausijärgses eas naistel. 


\section{Kokkuvõtteks}

Kui Hella Keem reflekteeris oma välitööpõhimõtteid, kirjeldas keeleteadlane, kuidas ta olevat oma esimestel välitöödel aru saanud, et viisaka külalisena käitumine pole otstarbekas. Et võimalikult kiire kontakt saavutada, pidi tungima kohe keelejuhile nii lähedale, et see suurest segadusest justkui lapsendaks sissetungija. Forsseeritud empaatia ja läheduse imperatiiv kuuluvadki sageli edukate välitööde retseptidesse. Uurija jaoks on välitööd enamasti eesmärgistatud ning see, kuidas jutule saadakse, on kõige järgneva eelduseks. Informandile naha alla pugemine on justkui õnnestunud välitööde eeldus. Uurija või informandi füüsilist heaolu või mugavust puudutavad kompromissid kuuluvad samuti sageli välitööde juurde. Välitööde osapooled on justkui Hella Keem ja Ann Rammo kitsas voodis ühiste linade vahel. Kas sellest forsseeritud intiimsusest ja äkilisest tutvusest tõuseb ka mingi "tõeline" ja võrdsetel alustel inimeste-vaheline suhe, see sõltub paljudest asjaoludest.

Uurija võtab välitöödele kaasa oma teadmistepagasi ja suhtlemisoskuse, aga ka oma empaatia, tunded ja eelarvamused. Kuigi uurija seksuaalsust ja religioosset tausta on olnud tavaks "objektiivsete" uuringute nimel varjata, on ka need väljal koos uurija elukogemuse ja eelistustega. Kuigi tänapäeval on tavaks rõhutada õnnestunud välitööde dialoogilisust, on välitööde struktuuri enamasti peidetud hierarhilisus. Välitööd on enamasti eesmärgistatud ja korraldatud nii, et informandid ei pruugi päris täpselt tajuda, mis põhjustel teatud teemasid vestluses käsitletakse või üleüldse lähedast suhtlemissituatsiooni luuakse. Teisalt konstrueerivad enamasti ka uurijad oma välitöökirjeldused sellistena, et neid kehalisi ja meelelisi kompromisse, mida nad ise on pidanud välitöödel tegema, ei rõhutata. Välitööde tegijad kardavad üle reageerida või kultuuridevahelises kommunikatsioonis ebaõnnestuda, aga on seotud ka uurijaeetikast lähtuvate vaikimisvannetega. Etteantud skriptist lähtuvalt püütakse saavutada läheduse teatud aste, kuid samas varjatakse nii välitöödel kui ka nende kirjalikes tulemustes liiga intiimseks kujunenud suhteid (nagu ka eos katkenud kontakte), aga ka seksuaalseid afääre või rünnakuid. 
Välitöödel juhtub alati palju rohkemat, kui välitöösalvestistelt võib hiljem kuulda. Eelarvamustest tingitud ehmatused ja kommunikatsioonihäired ei pruugi jäädvustustele või teadustöödesse jälgi jätta, kuid sellised piinlikud või naljakad hetked võivad olla välitöösituatsiooni kõigile osapooltele valgustuslikud. Sellised häired võivad küll rikkuda illusiooni täielikust üksteisemõistmisest ja ühisest keelest, kuid need paljastavad eelarvamusi ning õpetavad nägema näiteks soo, seksuaalsuse ja võimuga seotud struktuure ja hierarhiaid.

Artikli valmimist on toetanud Haridus- ja Teadusministeeriumi uurimisprojekt IUT 22-4 "Folkloor kultuurilise kommunikatsiooni protsessis: ideoloogiad ja kogukonnad”, Euroopa Liit Euroopa Regionaalarengu Fondi kaudu (Eesti-uuringute Tippkeskus) ja KONE fondi ja Helsingi Ülikooli uurimisprojekt "Omistajuus, kieli ja kulttuuriperintö - Kansanrunousideologiat Suomen, Karjalan tasavallan ja Viron alueilla”.

\section{Arhiiviallikad}

TÜ EMSA - Tartu Ülikooli eesti murrete ja sugulaskeelte arhiiv

ERA, DH - Eesti Kirjandusmuuseum, Eesti Rahvaluule Arhiivi digitaalsalvestiste kogu

\section{Kirjandus}

Cesara, Manda 1982. Reflections of a Woman Anthropologist: No Hiding Place. New York: Academic Press.

Dubisch Jill 1995. Lovers in the field: sex, dominance, and the female anthropologist. - Kulick, Don \& Willson, Margaret (toim). Taboo: Sex, Identity, and Erotic Subjectivity in Anthropological Fieldwork. London \& New York: Taylor \& Francis Routledge, 29-50.

Evans, Anya 2017a. Tinder as a Methodological Tool. - Allegra Lab: Anthropology, Law, Art \& World (http://allegralaboratory.net/tinderas-a-methodological-tool/ - 19.04.2018).

Evans, Anya 2017b. Follow up: \#Tinder as a research method. - Allegra Lab: Anthropology, Law, Art \& World (http://allegralaboratory.net/ follow-up-tinder-as-a-research-method/ - 20.04.2018). 
Kalkun, Andreas 2007. Nähtamatu ja nähtav pärimus. Seto rahvaluule kogumisest ning menstruatsiooni ja sünnitusjärgse käitumisega seotud tabudest - Ariadne Lõng: nais- ja meesuuringute ajakiri VII, 3-18 (https://enut.ee/files/ariadne_long_2007.pdf-20.04.2018).

Kalkun, Andreas 2015. Seto laul eesti folkloristika ajaloos. Lisandusi representatsiooniloole. Eesti Rahvaluule Arhiivi Toimetused 33. Tartu: Eesti Kirjandusmuuseumi Teaduskirjastus.

Kalkun, Andreas; Vuola, Elina 2017: The Embodied Mother of God and the Identities of Orthodox Women in Finland and Setoland. Religion and Gender 7 (1), 18-41 (http://doi.org/10.18352/rg.10165 20.04.2018).

Keem, Hella 1962. Kuidas minust sai murdekoguja. - Kodumurre 3-4. Tallinn: Eesti Teaduste Akadeemia Emakeele Selts, 28-38.

Keem, Hella 1987. Õpinguist, õpetajaist ja murdeuurimisest. - Emakeele Seltsi aastaraamat 31, Lähedalt ja kaugelt. Tallinn: Teaduste Akadeemia, Kirjastus Eesti Raamat, 137-172.

Kulick, Don \& Willson, Margaret (toim) 1995. Taboo: Sex, Identity, and Erotic Subjectivity in Anthropological Fieldwork. London and New York: Taylor \& Francis Routledge.

Larsen, Timothy 2016. The Slain God: Anthropologists and the Christian Faith. Oxford University Press.

Malinowski, Bronislaw 1967. A Diary in the Strict Sense of the Term. London: Routledge.

Newton, Esther 1993. My Best Informant's Dress: The Erotic Equation in Fieldwork. - Cultural Anthropology 8 (1; veebruar), 3-23.

Newton, Esther 2000. Margaret Mead Made Me Gay. Personal Essays, Public Ideas. Durham and London: Duke University Press.

Rabinow, Paul 2007. Reflections on Fieldwork in Morocco. 2nd edition. Foreword by Robert N. Bellah, Afterword by Pierre Bourdieu. Berkeley, Los Angeles, London: University of California Press.

Siikala, Anna-Leena 1984. Tarina ja tulkinta. Tutkimus kansankertojista. Suomalaisen kirjallisuuden seuran toimituksia. Helsinki: SKS.

VVMS 2011 = Käsi, Inge (koost). Vanapärase Võru murde sõnaraamat. Rõuge, Vastseliina, Setu. Tallinn: Eesti Keele Sihtasutus.

Väisänen, Armas Otto 1924. Syntymä, lapsuus ja kuolema. Setukaisten tapoja ja uskumuksia. - Kalevalaseuran vuosikirja 4. Helsinki: WSOY, 193-223.

Väisänen, Armas Otto 1969. Vepsäläisten luona v. 1916. - Kalevalaseuran vuosikirja 49. Porvoo; Helsinki, 272-288.

Väisänen, Armas Otto 1970. A. O. Väisäsen muistelmia. - Kalevalaseuran vuosikirja 50. Helsinki, 6-74. 
Väisänen, Armas Otto. 1992. Leisiö, Timo (toim). Setumaalta Harjumaalle. A.O Väisäsen tutkimusmatka Viroon vuonna 1913. Tamperen Yliopisto. Kansanperinteen laitos. Julkaisuja n:o 16. Tampere.

\section{Summary}

\section{In bed with the informant. Familiarity and intimate topics during fieldwork}

Keywords: fieldwork, intimacy, sexuality, taboos

The article reflects on the activities taking place during fieldwork with a focus on questions and problems related to sexuality and intimacy that can occur upon addressing intimate and taboo topics. Persons conducting fieldwork today are required to be very empathetic and able to build a trusting and close connection with the person with whom they are conversing. But compromises on the physical wellbeing and comfort of the researcher or the informant are also often a part of fieldwork In addition to intellectual or mental challenges, fieldwork is often a very physical experience. Collectors try to blend seamlessly into the physical space provided by the person they are conversing with and adapt to the rules of the field to ensure that the collection process is successful.

At the same time, researchers tend to design their fieldwork descriptions in a manner that does not emphasise the physical and mental compromises that they personally have had to make over the course of their fieldwork. Based on the provided script, researchers attempt to reach a certain level of interpersonal closeness during fieldwork while also covering up any problems occurring in the field. People performing fieldwork are afraid to overreact or fail in intercultural communication. They are also bound by oaths of silence arising from research ethics. Resulting from this, relationships that become too intimate in the field, along with sexual affairs or assault, are hidden.

Researchers bring their knowledge base and communication skills along for fieldwork and the same applies to their empathy, feelings and prejudice. Even though tradition calls for the sexuality and religious background of the researcher to be hidden away in the name of "objective" research, these, along with life experience and preferences, accompany the researcher in the field. Today, it is customary to emphasize how successful fieldwork builds dialogue, but the structure of fieldwork tends to be based on hierarchies. Fieldwork usually serves a particular purpose and is organised in such a way that does not allow the informants to fully comprehend the reason why certain topics are talked about or why a close communicative situation 
is established in the first place. Topics related to sex, intimacy and taboos seem to have the capacity to reveal some hidden aspects in the communication taking place during fieldwork, such as structures and hierarchies related to sexuality and power. 


\section{PILDI SISSE MINEK. Artikleid välitööde alalt}

\section{Koostanud ja toimetanud EDA KALMRE}

http://www.folklore.ee/rl/pubte/ee/cf/pildisisse

ISBN 978-9949-586-93-6

DOI $10.7592 / \mathrm{TF} 11$

Tartu 2019

Trükis ilmunud:

Pildi sisse minek. Artikleid välitööde alalt.

Tänapäeva folkloorist 11. Tartu 2019

Sarja peatoimetaja: Eda Kalmre

Kogumiku koostaja ja toimetaja: Eda Kalmre

Keeletoimetaja: Asta Niinemets

Kaanekujundus: Artur Kuus

Küljendus: Diana Kahre

Veebiväljaanne: Diana Kahre

Trükitud Eesti Kultuurkapitali toetusel. Väljaande valmimine on seotud Euroopa Liidu Euroopa Regionaalarengu Fondi (Eesti-uuringute Tippkeskus) ja Eesti Haridus- ja Teadusministeeriumi uurimisprojektiga IUT 22-5. Väljaande valmimist on toetanud Akadeemiline Rahvaluule Selts.

E-raamatu valmimist toetas: EKKM14-344 Eesti keele, kultuuri ja folkloori kasutusalade laiendamine ja tutvustamine elektroonilistel infokandjatel.

(C) Eesti Kirjandusmuuseum 2019

(C) Eda Kalmre ja autorid

(C) Artur Kuus 